\title{
IMPROVING STUDENTS' WRITING SKILL USING BRAINSWRITING STRATEGY
}

\author{
Sintawati Yulianti ${ }^{1}$, Siska Nuraeni $^{2}$, Aseptiana Parmawati ${ }^{3}$ \\ ${ }^{1}$ IKIP Siliwangi \\ ${ }^{2}$ IKIP Siliwangi \\ ${ }^{3}$ IKIP Siliwangi \\ ${ }^{1}$ Shintawatiyulianti@gmail.com, ${ }^{2}$ siscanuraeni08@gmail.com, ${ }^{3}$ aseptianaparmawati@gmail.com
}

\begin{abstract}
Writing is one of important skill in English subject beside the other skills. To improve the students' writing skill, we have to know what strategy is the most suitable for the students'. This research used Classroom Action Research. The research was on two cycles with total meetings were seven; three meetings were for tests, and four meetings were for treatment. Each cycle covered the step of planning, acting, observing, and reflecting. The population of this research was the Seventh Grade Students of SMP Pandu Nusantara in the academic year of 2018/2019 which consisted of 30 students. The average score of pretest was 45 . After the implementation of brainswriting strategy in every cycle, the students' writing skill score were getting better. It can be seen from the research of students' average score Cycle 1 was 50 and Cycle was 71 . It can be concluded that brainswriting strategy can improve students' writing skill and improve writing classroom into a better situation.
\end{abstract}

Keywords: Brainswriting, Writing skill, CAR

\section{INTRODUCTION}

In Indonesian, teaching and learning are important for human life. All people should have an education. In this case, study English is important to all people, especially for our generation because English is an International language and it has been used spread all over the world. Most people consider to learning English as difficult, especially in writing. Brown (2004: 255) as cited in Rahmadhani and Kumala, (2014)) state that "Writing is a process to create some ideas of students' knowledge to be a written". Blanchard and Root (1998: 1) as cited in Mundriyah and Parmawati (2016) state that learning to write in a new language is not always easy.

In addition, Scott (1990: 69) as cited in (Virdyna, 2016) defines Writing is an interesting activity, it can give students some advantages although basically there are difficulties in writing but it is still a useful, essential, integral and enjoyable part of the foreign language lesson. Writing involves several components which have to be considered including word choice, use of appropriate grammar, syntax, mechanics, and organization of ideas into coherent and cohesive form (Gebhard, 1996 cited in Apsari, 2017). Because it lets students express their personalities even guided activities can include choices for the students, like the copying the story about something. 
Writing is one of important skill in English subject beside the other skills. Eventhough witing skill is important, it does not get enough attention and proper time allocation in the teaching and learning process (Parmawati, 2013). According curriculum KTSP 2006 (Kurikulum Tingkat Satuan Pendidikan) as cited in (Rahmadhani and Kumala, 2014). The students have to have knowledge about the elements of writing in order to deliver a good writing. Furthermore, it is stated that writing is one of the most challenging skills for students (Adas and Bakir, 2013) as cited in ( Sari and Fitrawati, 2018) state that the students are expected to be able to write and understand the meaning of functional text and short essay such as narrative, descriptive and recount to be interacted in student's daily life. Thus, the teachers have to be able to guide the students to write well because it not easy for students.

English teacher tends to use Bahasa Indonesia during classroom activity therefore, based on the writers pre-observation in SMP Pandu Nusantara, it was found out that the students did not understand about writing. Most of students did not know how to write well. There are some problems that the writer found in writing class. The problem is most of students were difficult to find and others do not have idea in writing. It makes them difficult to do brainswriting. Michalko (2007: 77) in ( Oktavia, Martono, and Wartiningsih, 2016), stated brainswriting strategy is a strategy used by the teacher in writing. It is almost similiar to brainstorming. Braw and clerical techniques via Wilson (2013) as cited in (Nurzalinda, Putri \& Suhadi, 2018) defines, brainswriting is a method for quickly generating ideas by asking participants to compose their ideas on paper and exchanging ideas writing about tinkering with what happens to brainstorming techniques.

Beside the students problem the writers also found other problems come from the teacher. Most of them used monotonous strategy, it makes students not interesting in learning writing. The teacher only explained about generic structure of the text without explaining meaning from descriptive text. In teaching writing the teacher only gave topic without helping the students to develop their ideas. Unfortunately, the teachers do not guide them how to write well. It makes most students were bored in learning writing process.

\section{METHOD}

In this research the writers used Classroom Action Research is a given to a particular way of researching your own learning. It is a practical way of looking at your practice in order to check whether it is as you feel it should be. If you feel that your practice needs attention in some way you will be able to take action to improve it, and then produce evidence to show in what way the practice has improved (Purwati, Trainingand, \& Faculty, 2017)

In addition, D. Hopkins in his book ( Hopkins, D. (2008)) the title A Teacher's guide to classroom action research is a from of self-reflektif inquiry undertaken by participants in a social (including education) situation in order to improve the rationality and of (a) their own social or educational practices justice (b) their understanding of these practices, and (c) the situastions in which practices are carried out.

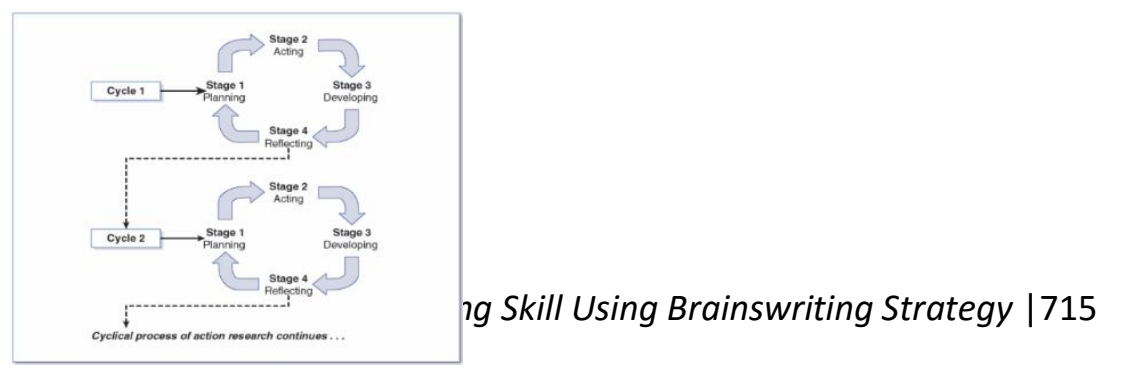


(Adapted from Mertler and Charles, 2011)

Figure 1 Cycling Process of Classroom action Research

There are four steps of typical action research model; they are divided into certain cycles of action starting from stage 1 (planning), stages 2 (acting), stage 3 (observing), and stage 4 (reflecting). The cycle stopped if the students had reached the target score stated in school KKM (Kriteria Ketuntasan Minimal), that is 70 as the minimum score for English subject at the Junior High School in SMP Pandu Nusantara. In other hand, if the students cannot reach the target score which was stated in school KKM, this cyclical process of action research should be continued.

The research brought into two cycles which each cycle contained pretest and posttest. The subject study was the first semester students of senior high school level which consisted of 30 students. There were total seven meetings covered on those two cycles; three meetings were for tests, and the other four meetings were for doing treatment. The treatment was teaching writing, especially discussion, with the application of Brainswriting strategy.

The instruments used in this research were observation and tests. The tests were used to test the students on pretest, posttest 1 and posttest 2. The tests given consisted of 20 items in the form of fill in the blank questions. The strategy sections should be brief, but they should include sufficient technical information to allow the experiments to be repeated by a qualified reader. Only new methods should be described in detail. Cite previously published procedures in References.

\section{RESULTS AND DISCUSSION}

\section{Results}

In this Classroom Action Research, the writers conducted two cycles. In this research, writers taught writing descriptive text by using brainswriting 6-3-5 strategy. The result of each cycle will be organized on four steps of CAR, namely: (1) planning, (2) acting, (3) Observing, and (4) reflecting.

\section{Pre-cycle}

The first step in making classroom action research, the writers began with an observation to know the condition of teaching learning in the classroom when the writing skill is implemented. In this activity the teacher taught students used conventional method. Then, the teacher gave pretest (written test) to check the students' writing skill on descriptive text.

Cycle I. On planning section, the writers prepared some lesson plans to teach conditional sentences. Lesson plans were made to be implemented on treatment 1 and 2, which contained some prosedures of CAR to teach descriptive text. Come to the next step, it is acting. In this step, the writer came to the class four times. 


\section{The first cycle}

\section{Action}

\begin{tabular}{|c|c|c|c|}
\hline No & Steps & writers' activity & Teachers' Activity \\
\hline 1. & Planning & $\begin{array}{l}\text { writers and teacher discussed the } \\
\text { implementation of brain writing 6-3-5 } \\
\text { technique } \\
\text { Arranging a lesson plan based on the } \\
\text { teaching material. } \\
\text { Preparing the teaching material. }\end{array}$ & $\begin{array}{l}\text { Preparing the teaching } \\
\text { material and students' } \\
\text { attendance list. }\end{array}$ \\
\hline 2. & Acting & $\begin{array}{l}\text { writers and teacher together enter the } \\
\text { classroom. } \\
\text { writers introduced brain writing 6-3-5 } \\
\text { technique } \\
\text { writers explain how to use brain } \\
\text { writing 6-3-5. Students do brain writing } \\
6-3-5 \text { in a group. } \\
\text { writers asked to arrange the ideas into a } \\
\text { paragraph as a test to evaluate the } \\
\text { students. }\end{array}$ & $\begin{array}{l}\text { Teacher greeted and checked } \\
\text { the students' attendance. } \\
\text { Teacher explain the } \\
\text { descriptive text. } \\
\text { Teacher asked students } \\
\text { about their problem in } \\
\text { previous lesson. }\end{array}$ \\
\hline
\end{tabular}
3. Observing The writers used observation checklist Teacher helped to observe to observed studentse activity. students during brain writing Observe students respond toward brain 6-3-5 was implemented writing 6-3-5

\begin{tabular}{ll}
\hline 4. Reflecting & writers analyzed the weakness and \\
& strengthen of implementation \\
& Brainswriting 6-3-5 \\
& writers made reflection and conclude \\
& the result of the first cycle.
\end{tabular}
The teacher and writers discuss about teaching and learning process that have been done to find the weakness and how to improve it in the next meeting.
The teacher and writers evaluate the learning process and analyze the result of observation checklist to find out the improvement of students ${ }^{\text {ee }}$ writing skill on descriptive text taught by using brain writing 6-3-5. 


\section{The second cycle}

\begin{tabular}{|c|c|c|c|}
\hline No & Steps & writers' activity as collaborator & Teachers' Activity \\
\hline 1. & Planning & $\begin{array}{l}\text { Arranging a lesson plan based on } \\
\text { the teaching material. } \\
\text { Prepare the material, the test } \\
\text { instrument and the observation } \\
\text { checklist. }\end{array}$ & $\begin{array}{l}\text { Preparing the material } \\
\text { andstudents' attendance } \\
\text { list. }\end{array}$ \\
\hline 2. & Acting & $\begin{array}{l}\text { writers and teacher together enter } \\
\text { the classroom. } \\
\text { writers asked students to write } \\
\text { ideas about their trip experiences } \\
\text { to some places. Then, students did } \\
\text { a brain writing } 6-3-5 \text { technique. } \\
\text { The writers asked to arrange the } \\
\text { ideas into a paragraph as a test to } \\
\text { evaluate the students. }\end{array}$ & $\begin{array}{l}\text { Teacher greeted and } \\
\text { checked } \\
\text { attendance. } \\
\text { Teacher reviewed the } \\
\text { previous material. }\end{array}$ \\
\hline
\end{tabular}

3. Observing The writers used observation checklist to observed students ${ }^{\text {ee }}$

Help to observe the activity.

students $^{\text {ee }}$ participation.

4. Reflecting The writers and teacher discuss

The teacher and writers about teaching learning process evaluate the teaching that had been done. The result of observation was analyzed, so it learning process and analyze the result of could be seen the improvement of students ${ }^{\text {ee }}$ writing skill on descriptive text after taught using brain writing 6-3-5 technique observation checklist to find out the improvement of students se writing skill on descriptive text taught by using brain writing 6-35 technique The teacher and writers reflected the activities that have been done. The result of the analysis could be used as review that by using brain writing 6-3-5 technique could improve students ${ }^{\text {ee }}$ writing skill on descriptive text.

There were much improvement in every meeting. The improvement were as follows: (1) their score on post-test 2 was increased. From 45 for pretest, it was improved to be 50 . and for the posttest 2 , their score became 71 , and (2) their quality of learning shown from their attitude and behaviour during joining the lesson. 
The detail result of score of the test can be seen on table 3 below.

Table 3.Improvement on students' score of the tests.

\begin{tabular}{cccc}
\hline & Pretest & Posttest 1 & Posttest 2 \\
\hline Minimum score & 30 & 33 & 60 \\
\hline Maximal score & 60 & 67 & 87 \\
\hline Mean score & 45 & 50 & 71 \\
\hline
\end{tabular}

While the improvements on attitude and behavior are presented in table 4 below:

Table 4.Improvement on attitude and behavior

\begin{tabular}{lll}
\hline Points & \multicolumn{1}{c}{ Former condition } & \multicolumn{1}{c}{ Improvements } \\
\hline Activeness & At the first meeting, The students are more \\
students tend to be passive daring to speak, and \\
and difficult to express express their ideas when \\
their ideas because still discussing. \\
have a minimal \\
vocabulary. \\
The students looked Students are more \\
confused, they were not confident to give their \\
sure what to do. They still ideas. The students began \\
feel uncomfortable when to show their grammar \\
describing material using development by believing \\
this technique because in speaking when \\
they are leading to explore explaining a topic that the \\
their vocabulary and writer gave. \\
grammar. \\
The students' curiosity to The student more \\
startwriting was very low interested for share their \\
because of their lack of ideas about topic that \\
vocabulary and grammar. given writers. \\
And they only follow the \\
teacher's guidance to do it. \\
The main purposes using The student more \\
brainswriting is to train interested in writing when \\
students to be more use the brainswriting \\
courageous in writing mehod and they are begin \\
skills and to improve the to show their vocabulary \\
students knowledge and grammar. \\
vocabulary and grammar \\
their writing skill is very \\
low and tends to be \\
passive when share their \\
ideas.
\end{tabular}




\section{Discussion}

Before the teacher start teaching using brainwriting strategy, the teacher prepare teaching material, lesson plan, time allocation and media.

In pre-teaching activity, the teacher can do some steps, such as greeting, checking attendance list and brainwriting to the students. In the whlist activity, the teacher applies by using brainswriting and. In post learning activity, the teacher concludes the material.

\section{CONCLUSION}

The Conclusion should contain the confirmation of the problem that has been analyzed. The study was conducted on two cycles with a total of seven meetings; three meetings for the test, and four meetings for the test, and four meetings for treatment. Each cycle includes the steps of planning, action, observation, and reflection. From the data collected by the writers, it can be concluded that the mastery of vocabulary and grammar in the skills of writing high school students increases. Improvements include two points, namely: (1) increasing their average score. The average of pretest was 45 , the average score of posttest 1 was 50 , while the average score of posttest 2 was 71. (2) improvement of their attitudes and behaviour. This can be seen from their increased liveliness, fun, curiousity and knowledge.

Finally, some suggestions from the writers can be taken. In teaching writing, especially descriptive text, teachers need to try many strategy to improve students ability and understanding. One excellent method to improve grammar and vocabulary development is writing skill discussed using Brainwriting that have been provided by writers. It is highly recommended for teachers to teach writing skills. Instead of using monotonic methods, this strategy can be used as a refresher for students so boredom during the lessons can be reduced.

\section{ACKNOWLEDGMENTS}

Alhamdulillahirabbil ' alamin. Praise be to Allah SWT who has anabled the writers to finish this article. Peace and salutation go to Rasulullah SAW. Thanks to parents, family and our lecturers during the completing this article.

\section{REFERENCES}

Apsari, Y. (2017). The Use Of Picture Series In Teaching Writing Recount Text. Eltin Journal, Journal Of English Language Teaching In Indonesia, 5(2), 51-56.

Hopkins, D. (2008). A Teacher's Guide to Classroom-based Research.

Mundriyah, M., \& Parmawati, A. (2016). Using Think-Pair-Share (Tps) To Improve Students'writing Creativity (A Classroom Action Research In The Second Semester Students Of Stkip Siliwangi Bandung). P2m Stkip Siliwangi, 3(2), 84-91.

Nurzalinda, A., Putri, H., \& Suhadi, A. (2018). Using of Brainwriting to Write a Poem for First Semester Students of English Study Program Muhammadiyah University of Bengkulu. 4(1), 26-34.

Oktavia, W., Martono., Wartiningsih, A. (2016) Penerapan Teknik Brainwriting Untuk Meningkatkan Menulis Wacana Narasi Pada Siswa Kelas Xi Tphp Smk, No Title. 1-15.

Parmawati, A. (2013). The effectiveness of Think-Pair-Share (TPS) to Teach Writing Viewed From Students Creativity (Doctoral dissertation, SEBELAS MARET UNIVERSITY). 
Purwati, R., Trainingand, T., \& Faculty, E. (2017). the Use of Brainwriting Strategy To Improve the Students' Writing Skill in Descriptive Text ( Classroom Action Research of Second Grade Students At Mtsn1Susukan in the Academic Year of.

Rahmadhani, S., Kumala, R., (2014). Teaching Writing Of Descriptive Text By Combining Brainwriting And Mind Maps Strategies At Junior High By. 1-7.

Sari, E. K., Fitrawati (2018). Journal of English Language Teaching USING 6-3-5 Brainwriting In Helping Senior High School Students Doing Brainstorming In. 7(3).

Virdyna, N. K. (2016) Teaching Writing Skill By Using Brainwriting. (2016). 1, 67-77. 